\title{
ANALISIS COD, DO, KANDUNGAN POSFAT DAN NITROGEN LIMBAH CAIR TAPIOKA
}

\author{
${ }^{1} \mathrm{Ni}$ Luh Gede Ratna Juliasih, ${ }^{1}$ Rian Fadlya Amha \\ ${ }^{1}$ Jurusan Kimia Fakultas Matematika dan Ilmu Pengetahuan Alam Universitas Lampung \\ J1. Sumantri Brodjonegoro No. 1 Bandar Lampung 35145 \\ niluhratna.juliasih@fmipa.unila.ac.id
}

\begin{tabular}{|l|}
\hline $\begin{array}{l}\text { Artikel Info } \\
\text { Diterima } \\
\text { tanggal } \\
12.12 .2018 \\
\text { Disetujui } \\
\text { publikasi } \\
\text { tanggal } \\
\text { 30.04.2019 } \\
\text { Kata kunci : } \\
\text { limbah } \\
\text { tapioka, DO, } \\
\text { COD, UV-VIS }\end{array}$ \\
\hline
\end{tabular}

\section{ABSTRAK}

Penelitian ini dilakukan untuk menentukan suhu, $\mathrm{pH}$, oksigen terlarut (DO), Kebutuhan oksigen Kimiawi (COD), nitrogen total, dan fosfat total pada limbah cair industri tapioka. Suhu limbah cair ditentukan dengan termometer, diperoleh sebesar $27,3^{\circ} \mathrm{C}$, dan $\mathrm{pH}$ yang ditentukan dengan $\mathrm{pH}$ meter diperoleh sebesar 4,77, yang menunjukkan bahwa limbah cair tersebut bersifat asam. Kadar DO sebesar 2,14 mg/L sedangkan kadar COD terukur adalah sebesar $2.864 \mathrm{mg} / \mathrm{L}$. Total fosfat diukur berdasarkan metode asam askorbat, diperole sebesar 3,145 $\mathrm{mg} / \mathrm{L}$, sedangkan total nitrogen diukur berdasarkan metode Kjeldahl, diperoleh sebesar $212 \mathrm{mg} / \mathrm{L}$.

\section{ABSTRACT}

This research was conducted to determine the temperature, $\mathrm{pH}$, dissolved oxygen (DO), Chemical Oxygen Demand (COD), total nitrogen and total phosphate in wastewater of tapioca industry. The temperature was obtained $27.3^{\circ} \mathrm{C}$, and $\mathrm{pH}$ determined by the $\mathrm{pH}$ meter obtained was 4.77 , which indicates that the liquid waste is acidic. The DO levels were $2.14 \mathrm{mg} / \mathrm{L}$ while the COD levels were $2.864 \mathrm{mg} / \mathrm{L}$. on the other hand the total phosphate was measured by the ascorbic acid method, obtained at $3.145 \mathrm{mg} / \mathrm{L}$, and the total nitrogen with the Kjeldahl method, obtained at $212 \mathrm{mg} / \mathrm{L}$

\section{PENDAHULUAN}

Indonesia adalah penghasil singkong urutan keempat dunia setelah Nigeria, Brasil, dan Thailand, dan Provinsi Lampung merupakan penghasil singkong terbesar (24\%) di Indonesia. Jumlah produksi singkong di provinsi Lampung pada tahun 2016 mencapai 7.387.084 ton (BPS Provinsi Lampung, 2016). Singkong biasanya hanya digunakan sebagai pakan ternak dan bahan pangan tradisional nomor tiga setelah beras dan jagung, namun saat ini singkong sudah digunakan sebagai bahan industri yang tingkat kebutuhannya mulai bersaing dengan kebutuhan konsumsi langsung (Prihandana, 2007). Tingginya produksi singkong mendorong berdirinya industri tapioka sehingga ada sekitar 70 industri tapioka yang telah berkembang di provinsi Lampung.

Berkembangnya industri tentunya memberikan dampak positif pada peningkatan perekonomian masyarakat. Akan tetapi, adanya limbah industri juga memberikan dampak 
negatif berupa pencemaran lingkungan. Rahmatul et al., (2013) menyatakan bahwa secara umum industri tapioka menghasilkan $70 \%$ limbah dari berat singkong yang diolah, yang terdiri dari limbah padat dan limbah cair. Limbah padat industri tapioka biasanya berupa onggok untuk pakan ternak, sedangkan limbah cairnya berupa limbah yang berasal dari bekas cucian singkong berkulit (banyak mengandung lumpur), limbah cair dari proses pengendapan (kondisinya lebih kental dari limbah cair dari proses perendaman dan pencucian daging singkong) serta limbah perendaman aci dalam larutan garam (Suprapti, 2005).

Limbah cair merupakan limbah yang paling berdampak terhadap lingkungan karena masih mengandung bahan organik dan senyawa asam yang berbahaya (Yang et al., 2008). Kandungan organik dalam limbah cair tepung tapioka ini berkisar 7000-30000 ppm (Rahmatul et al., 2013) Apabila limbah cair ini langsung dibuang ke lingkungan maka akan sangat potensial menurunkan kandungan oksigen terlarut di perairan umum. Oleh karena itu, pengolahan yang tepat bagi limbah cair sangat diutamakan agar tidak mencemari lingkungan.

Ada banyak parameter yang dapat digunakan untuk mengukur apakah suatu limbah cair telah layak dibuang ke lingkungan, yaitu parameter fisik, parameter kimiawi dan parameter biologi. Parameter fisik dalam limbah cair meliputi padatan total, kekeruhan, warna, suhu, bau dan rasa. Parameter kimiawi ditentukan oleh kandungan bahan/unsur yang membentuk sifatsifat kimia dari air yang meliputi : tingkat keasaman $(\mathrm{pH})$, alkalinitas, kadar besi, mangan, klorida, fosfor, sulfur, nitrogen, logam berat, fenol, BOD, COD, lemak dan minyak, karbohidrat dan protein. Parameter biologi ditentukan oleh kandungan organisme seperti bakteri dan organisme lainnya (Alaerts dan Santika, 1984). Peraturan Menteri Lingkungan Hidup Republik Indonesia No. 5 Tahun 2014 tentang baku mutu air limbah telah memberikan ketentuan atau syarat air limbah dapat dibuang ke lingkungan.

Penelitian ini bertujuan untuk mengukur kadar beberapa parameter limbah cair industri tapioka, meliputi suhu, $\mathrm{pH}$, oksigen terlarut/ issolved Oxygen (DO), kebutuhan oksigen kimiawi/Chemical Oxygen Demand (COD), total nitrogen, dan total fosfat sehingga dapat memberikan informasi mengenai kelayakan limbah cair tersebut untuk dibuang ke lingkungan.

\section{METODE}

\section{Alat dan Bahan}

Bahan-bahan yang digunakan yaitu limbah tapioka yang diperoleh dari pipa tempat pembuangan akhir (TPA) sebuah pabrik di Lampung Tengah, asam klorida ( $\mathrm{HCl}$ ), asam sulfat 
$\left(\mathrm{H}_{2} \mathrm{SO}_{4}\right)$, merkuri sulfat $\left(\mathrm{HgSO}_{4}\right)$, kalium dikromat $\left(\mathrm{K}_{2} \mathrm{Cr}_{2} \mathrm{O}_{7}\right)$, perak sulfat $\left(\mathrm{Ag}_{2} \mathrm{SO}_{4}\right)$, fero ammonium sulfat (FAS), indikator feroin, kalium antimonil tartrat, amonium molibdat, asam askorbat, kalium dihidrogen fosfat $\left(\mathrm{KH}_{2} \mathrm{PO}_{4}\right)$, indikator fenolftalein, selenium, natrium hidroksida $(\mathrm{NaOH})$, asam borat, indikator metil merah-metil biru (MM-MB), dan akuades.

Peralatan yang digunakan yaitu oven, neraca analitik KERN:ABS 220-4, peralatan Kjeldahl Behr S4, DO Meter Milwaukee MI 190, pH Meter Hanna HI-83141, spektrofotometri UV-Vis Hitachi U-2010 dan peralatan gelas seperti labu ukur, gelas ukur, beaker glass, erlenmeyer, tabung digesti COD, tabung reaksi, corong gelas, pipet tetes, buret $50 \mathrm{~mL}$, mikroburet $10 \mathrm{~mL}$, dan termometer.

\section{Prosedur}

Pengukuran pH dilakukan dengan pH meter Hanna HI-83141, sedangkan pengukuran suhu dilakukan dengan termometer, serta pengukuran kadar DO dilakukan dengan DO meter Milwaukee MI 190.

\section{Analisis Kadar COD}

Sebanyak $15 \mathrm{~mL}$ sampel dimasukkan ke dalam erlenmeyer $100 \mathrm{~mL}$, ditambahkan berturut-turut $0,1 \mathrm{~g} \mathrm{HgSO}_{4}, 5 \mathrm{~mL} \mathrm{~K}_{2} \mathrm{Cr}_{2} \mathrm{O}_{7} 0,25 \mathrm{~N}$, serta campuran asam sulfat dan perak sulfat (7,5 mL), lalu dihomogenkan. Campuran dimasukkan ke tabung COD, ditambahkan batu didih, ditutup, kemudian direfluks selama 2 jam dengan suhu $150^{\circ} \mathrm{C}$. Setelah dingin, campuran ditambahkan 2 tetes indikator feroin, dititrasi dengan FAS 0,1 N sampai terjadi perubahan warna hijau-biru menjadi merah-jingga (SNI 6989.73_2009).

\section{Analisis Total Fosfat}

Larutan kerja standar fosfat dibuat dengan tehnik pengenceran bertingkat dari larutan induk fosfat $500 \mathrm{mg} / \mathrm{L}$ yang dibuat dengan melarutkan $1,0975 \mathrm{~g} \mathrm{KH}_{2} \mathrm{PO}_{4}$ dengan aquades pada labu ukur $500 \mathrm{~mL}$. Konsentrasi larutan kerja standar yang digunakan adalah larutan kerja fosfat 0,0 mg/L, 0,2 mg/L, 0,4 mg/L, 0,8 mg/L, dan 1,0 mg/L. Larutan kerja dipipet masing-masing sebanyak $50 \mathrm{~mL}$ lalu dimasukkan ke labu erlenmeyer, ditambahkan 1 tetes indikator fenolftalein. Jika terbentuk warna merah muda maka ditambahkan tetes demi tetes $\mathrm{H} 2 \mathrm{SO} 45 \mathrm{~N}$ sampai warna hilang. Larutan campuran yang terdiri dari $\mathrm{H}_{2} \mathrm{SO}_{4} 5 \mathrm{~N}$, kalium antimonil tartrat, ammonium molibdat, dan asam askorbat ditambahkan sebanyak $8 \mathrm{~mL}$ dan dihomogenkan. Selanjutnya, larutan dimasukkan ke dalam kuvet untuk diukur serapannya dengan spektrofotometer UV-VIS pada panjang gelombang $880 \mathrm{~nm}$ dan dicatat nilai absorbansinya. Prosedur yang sama dilakukan terhadap sampel dengan perlakuan uji secara duplo. Kadar 
fosfat $(\mathrm{mg} / \mathrm{L})$ dihitung dengan : $\mathrm{C}$ x fp dengan $\mathrm{C}$ adalah kadar yang diperoleh dari hasil pengukuran dan fp adalah faktor pengenceran (SNI 06-6989.31-2005).

\section{Analisis Total Nitrogen}

Analisis total nitrogen menggunakan metode kjeldahl, dengan 3 tahapan proses yakni destruksi, destilasi, dan titrasi. Sebanyak $20 \mathrm{~mL}$ sampel ditambahkan 7,8 g selenium reagen mixture, selanjutnya ditambahkan $15 \mathrm{~mL} \mathrm{H}_{2} \mathrm{SO}_{4}$ pekat, dan didestruksi selama 150 menit. Hasil destruksi yang telah dingin ( \pm 15 menit) berbentuk seperti gel, selanjutnya ditambahkan larutan $\mathrm{NaOH} 50 \%$ w/w, 5 tetes indikator MM-MB, $20 \mathrm{~mL}$ asam borat $4 \%$ w/v, dan didestilasi. Destilat yang diperoleh, selanjutnya dititrasi menggunakan larutan $\mathrm{H}_{2} \mathrm{SO}_{4} 0,1 \mathrm{~N}$, lalu dicatat volume titran yang digunakan. Titik akhir titrasi ditandai dengan perubahan warna (ASTM D $3590-02)$.

\section{HASIL DAN PEMBAHASAN}

Sampel yang diambil dari pembuangan akhir (TPA) pabrik GGF (Great Giant Food) adalah sampel segar hasil produksi tapioka. Suhu sampel diukur di lapangan dan diperoleh bahwa sampel limbah cair industri tapioka memiliki suhu $27,3^{\circ} \mathrm{C}$. Sampel yang digunakan untuk analisis COD dan total nitrogen diawetkan dengan penambahan $\mathrm{H}_{2} \mathrm{SO}_{4}$ hingga $\mathrm{pH}<2$ dan didinginkan pada suhu $4^{\circ} \mathrm{C}$. Derajat keasaman $(\mathrm{pH})$ yang ditentukan dengan $\mathrm{pH}$ meter menunjukkan bahwa pH sampel adalah 4,77, yang berarti bersifat asam. Peraturan Menteri Lingkungan Hidup RI No. 5 tahun 2014 tentang Baku Mutu Air Limbah menyatakan bahwa pH yang ditoleransi pada limbah tapioka adalah pada rentang 6,0 - 9,0. Prayitno (2008) mengatakan nilai $\mathrm{pH}$ yang rendah menunjukkan bahwa di dalam sampel limbah telah terjadi aktivitas mikroorganisme yang mendegradasi bahan organik yang mudah terurai menjadi asam. Nilai pH dapat menunjukkan perlu atau tidaknya pengolahan pendahuluan terhadap limbah untuk mencegah terjadinya gangguan pada proses pengolahan limbah cair secara konvensional. Selanjutnya, hasil pengukuran DO didapatkan sebesar 2,14 mg/L.

\section{Analisis Kadar COD}

Analisis ini bertujuan untuk mengetahui jumlah bahan organik yang terkandung di dalam limbah cair. Chemical Oxygen Demand (COD) adalah jumlah oksigen yang diperlukan agar bahan buangan yang ada di dalam air dapat teroksidasi melalui reaksi kimia, dalam hal ini bahan buangan organik akan dioksidasi oleh kalium dikromat atau $\mathrm{K}_{2} \mathrm{Cr}_{2} \mathrm{O}_{7}$ yang digunakan sebagai sumber oksigen (oxidizing agent). Oksidasi terhadap bahan buangan organik akan mengikuti reaksi berikut ini: 


$$
\mathrm{C}_{\mathrm{a}} \mathrm{H}_{\mathrm{b}} \mathrm{O}_{\mathrm{c}}+\mathrm{Cr}_{2} \mathrm{O}_{7}{ }^{2-}+\mathrm{H}^{+} \longrightarrow \mathrm{CO}_{2}+\mathrm{H}_{2} \mathrm{O}+\mathrm{Cr}^{3+}
$$

Jadi, prinsip kerja pengukuran COD adalah reaksi antara $\mathrm{K}_{2} \mathrm{Cr}_{2} \mathrm{O}_{7}$ dengan zat organik yang ada dalam sampel, dengan asam sulfat-perak sulfat bertindak sebagai katalis. Agar kalium dikromat mengoksidasi bahan-bahan organik dengan sempurna, maka reaksi harus berlangsung dalam suasana asam kuat dan temperatur tinggi, sehingga reaksi dilakukan pada suhu $150^{\circ} \mathrm{C}$ dalam suasana asam sulfat. Katalis merkuri sulfat dan perak sulfat diperlukan masing-masing untuk mengatasi gangguan klorida dan menjamin oksidasi senyawa-senyawa organik kuat. Klorida dapat mengganggu analisis karena akan ikut teroksidasi oleh kalium bikromat sesuai dengan reaksi berikut ini:

$$
6 \mathrm{Cl}^{-}+\mathrm{Cr}_{2} \mathrm{O}_{7}^{2-}+14 \mathrm{H}^{+} \longrightarrow 3 \mathrm{Cl}_{2}+2 \mathrm{Cr}^{3+}+7 \mathrm{H}_{2} \mathrm{O}
$$

Gangguan ini dapat dihilangkan dengan penambahan merkuri sulfat $\left(\mathrm{HgSO}_{4}\right)$ pada sampel sebelum penambahan pereaksi-pereaksi lain. Ion merkuri akan bergabung dengan ion klorida membentuk merkuri-klorida, suatu kompleks yang dapat larut dan tahan oksidasi.

$$
\mathrm{Hg}^{2+}+2 \mathrm{Cl}^{-} \longrightarrow \mathrm{HgCl}_{2}
$$

Adanya kelebihan merkuri maka konsentrasi ion klorida menjadi sangat kecil sehingga tidak mengganggu oksidasi zat organik oleh kalium dikromat.

Penambahan kalium bikromat harus berlebih untuk memastikan bahwa hampir semua zat organik habis teroksidasi. Perubahan warna larutan dari kuning menjadi hijau kebiruan dikarenakan kalium dikromat dalam keadaan asam dan bersuhu tinggi akan mengalami reduksi menjadi ion kromium $\left(\mathrm{Cr}^{3+}\right)$. Selanjutnya, kalium dikromat yang tersisa di dalam larutan tersebut digunakan untuk menentukan berapa oksigen yang telah terpakai. Kelebihan kalium dikromat dihitung dengan cara titrasi menggunakan Ferro Ammonium Sulfat (FAS) dengan penambahan indikator feroin, dan terbentuknya warna coklat kemerahan menunjukkan teroksidasinya $\mathrm{Fe}^{2+}$ dari FAS menjadi $\mathrm{Fe}^{3+}$.

$$
6 \mathrm{Fe}^{2+}+\mathrm{Cr}_{2} \mathrm{O}_{7}^{2-}+14 \mathrm{H}^{+} \rightarrow 6 \mathrm{Fe}^{3+}+2 \mathrm{Cr}^{3+}+7 \mathrm{H}_{2} \mathrm{O}
$$

Hasil perhitungan COD pada sampel limbah cair tapioka memberikan kadar sebesar 2.864 $\mathrm{mg} / \mathrm{L}$, jauh melebihi ambang batas persyaratan yang ditetapkan dalam Peraturan Menteri Lingkungan Hidup RI No. 5 tahun 2014 tentang Baku Mutu Air Limbah yang menetapkan kadar COD maksimal adalah $300 \mathrm{mg} / \mathrm{L}$. Oleh karena itu perlu dilakukan pengolahan lebih lanjut terhadap limbah cair tapioka tersebut sebelum dibuang ke lingkungan.

doi: http://dx.doi.org/10.23960/aec.v4.i1.2019.p65-72 


\section{Analisis Total Fosfat}

Prinsip kerja dari penentuan total fosfat adalah reaksi antara ammonium molibdat dan kalium antimonil tartrat dengan ortofosfat dalam suasana asam. Keempat atom $\mathrm{O}$ pada asam fosfat digantikan oleh empat gugus $\mathrm{Mo}_{3} \mathrm{O}_{10}$ untuk membentuk senyawa asam fosfomolibdat. Asam fosfomolibdat kemudian direduksi oleh asam askorbat menjadi kompleks biru molibden dengan adanya kalium antimonil tartrat. Hasilnya terbentuk senyawa kompleks fosfomolibdenum biru, dan kadar fosfat yang terkandung dalam fosfomolibdenum biru kemudian dianalisis dengan speketrofotometri UV-VIS. Reaksi hanya dapat berlangsung dalam suasana asam sehingga sampel harus diasamkan terlebih dahulu dengan penambahan larutan asam sulfat (Kusumaningtyas, 2017).

$$
\begin{aligned}
& \left(\mathrm{NH}_{4}\right)_{6} \mathrm{Mo}_{7} \mathrm{O}_{24}+4 \mathrm{H}_{2} \mathrm{O} \longrightarrow 6 \mathrm{NH}_{4}^{+}+7 \mathrm{MoO}_{4}{ }^{2-}+8 \mathrm{H}^{+} \\
& \mathrm{H}_{2} \mathrm{PO}_{4}+12 \mathrm{MoO}_{4}+25 \mathrm{H}^{+} \longrightarrow \mathrm{H}_{3}\left[\mathrm{P}\left(\mathrm{Mo}_{3} \mathrm{O}_{10}\right)_{4}\right]+12 \mathrm{H}_{2} \mathrm{O} \\
& \mathrm{H}_{3}\left[\mathrm{P}\left(\mathrm{Mo}_{3} \mathrm{O}_{10}\right)_{4}\right]+4 \mathrm{H}^{+} \longrightarrow \mathrm{H}_{7}\left[\mathrm{P}\left(\mathrm{Mo}_{3} \mathrm{O}_{10}\right)_{4}\right]
\end{aligned}
$$

Hasil pengukuran diperoleh kadar fosfat yang terkandung pada limbah cair tapioka sebesar $6,38 \mathrm{mg} / \mathrm{L}$.

\section{Analisis Total Nitrogen}

Analisis total nitrogen yang menggunakan metode kjeldahl terdiri dari 3 tahapan, yaitu destruksi, destilasi dan titrasi (Legowo \& Nurwantoro, 2004). Proses pertama adalah destruksi atau penguraian sampel menjadi unsur-unsurnya yaitu C,H, O, N, S, dan P. Fungsi selenium reagent mixture yaitu sebagai katalisator untuk mempercepat oksidasi bahan organik (Sudjadi dan Rohman, 2004). Asam sulfat berfungsi untuk mengikat nitrogen dan juga menguraikan unsur-unsurnya. Reaksi yang terjadi pada proses destruksi adalah sebagai berikut :

$$
\mathrm{N}_{\text {organik }}+\mathrm{H}_{2} \mathrm{SO}_{4} \rightarrow\left(\mathrm{NH}_{4}\right)_{2} \mathrm{SO}_{4}+\mathrm{CO}_{2}+\mathrm{SO}_{2}+\mathrm{H}_{2} \mathrm{O}
$$

Indikasi bahwa proses destruksi telah selesai adalah larutan berwarna jernih kehijauan, seperti terlihat pada Gambar 1 . 


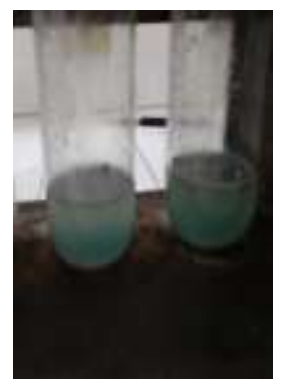

(a)

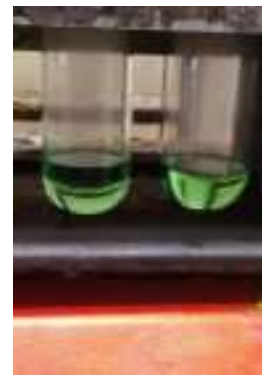

(b)

Gambar 1. Limbah Cair Tapioka (a) sebelum didestruksi (b) setelah didestruksi

Sampel hasil destruksi didinginkan sampai menjadi gel. Selanjutnya, proses distilasi dilakukan dengan penambahan $\mathrm{NaOH}$ berlebih, untuk memberikan suasana basa sehingga amonium sulfat dikonversi menjadi amonia $\left(\mathrm{NH}_{3}\right)$ dengan pemanasan dalam alat destilasi. Gas ammonia diserap dalam larutan asam borat yang telah ditambah indikator MM-MB sebagai penunjuk titik akhir gas ammonia yang telah terserap ditandai dengan perubahan warna destilat menjadi hijau muda. Reaksi yang terjadi pada proses distilasi adalah sebagai berikut:

$$
\begin{aligned}
\left(\mathrm{NH}_{4}\right)_{2} \mathrm{SO}_{4}(\mathrm{aq})+2 \mathrm{NaOH} & \rightarrow \mathrm{Na}_{2} \mathrm{SO}_{4(\mathrm{aq})}+2 \mathrm{H}_{2} \mathrm{O}_{(\mathrm{l})}+2 \mathrm{NH}_{3(\mathrm{~g})} \\
\mathrm{NH}_{3}+\mathrm{H}_{3} \mathrm{BO}_{3} & \rightarrow \mathrm{NH}_{4}^{+} \mathrm{H}_{2} \mathrm{BO}_{3}^{-}+\mathrm{H}_{3} \mathrm{BO}_{3}
\end{aligned}
$$

Destilat selanjutnya dititrasi menggunakan $\mathrm{H}_{2} \mathrm{SO}_{4} 0,1 \mathrm{~N}$ dan dititrasi hingga terjadi perubahan warna yang tetap, diperoleh kadar nitrogen total yang didapatkan yakni sebesar $212 \mathrm{mg} / \mathrm{L}$.

$$
\mathrm{NH}_{4} \mathrm{H}_{2} \mathrm{BO}_{3}+\mathrm{H}_{2} \mathrm{SO}_{4} \rightarrow\left(\mathrm{NH}_{4}\right)_{2} \mathrm{SO}_{4}+2 \mathrm{H}_{3} \mathrm{BO}_{3}
$$

Hasil analisis sampel limbah cair tapioka ini menunjukkan bahwa limbah bersifat asam, memiliki kandungan COD, fosfat dan nitrogen yang tinggi sehingga belum layak dibuang langsung ke lingkungan. Kandungan bahan organik yang tinggi, nitrogen dan fosfat pada limbah ini dapat dimanfaatkan untuk produksi biomassa dari mikroalga sehingga secara signifikan dapat mengurangi nitrogen, fosfat, bahan-bahan organik dan anorganik di dalamnya.

\section{KESIMPULAN}

Hasil karakterisasi limbah cair tapioka diperoleh bahwa limbah tesebut suhunya $27,3^{\circ} \mathrm{C}$ dengan $\mathrm{pH}$ 4,77, DO sebesar 2,14 mg/L, COD sebesar $2.864 \mathrm{mg} / \mathrm{L}$, total nitrogen sebesar 212 $\mathrm{mg} / \mathrm{L}$, dan total fosfat sebesar $6,38 \mathrm{mg} / \mathrm{L}$, yang secara umum menunjukkan bahwa limbah tersebut belum memenuhi baku mutu lingkungan berdasarkan Peraturan Menteri Lingkungan 
No. 5 Tahun 2014. Oleh karena itu, perlu dilakukan penanganan sebelum dibuang ke lingkungan, antara lain dimanfaatkan untuk produksi biogas melalui proses pengolahan secara anaerobik. Selain itu, kandungan senyawa organik yang tinggi pada limbah cair tapioka dapat dimanfaatkan sebagai media pertumbuhan untuk algae.

\section{DAFTAR PUSTAKA}

An American National Standard. 2002. Standard Test Methods for Total Kjeldahl Nitrogen in Water. ASTM D $3590-02$.

Alaerts, G. dan Santika, S.S. 1984. Metode Penelitian Air. Usaha Nasional. Surabaya.

Badan Pusat Statistik Provinsi Lampung. 2016. Lampung dalam angka 2015. Badan Pusat Statistik Provinsi Lampung. Lampung.

Badan Standardisasi Nasional. 2009. SNI 6989.73_2009. Air dan air limbah-Bagian 73: Cara uji kebutuhan oksigen kimiawi (Chemical Oxygen Demand/COD) dengan refluks tertutup secara titrimetri. Badan Standardisasi Nasional. Jakarta.

Badan Standardisasi Nasional. 2005. SNI 06-6989.31-2005. Air dan air limbah - Bagian 31: Cara uji kadar fosfat dengan spektrofotometer secara asam askorbat. Badan Standardisasi Nasional. Jakarta.

Kusumaningtyas, D. 2017. Analisa Kadar Fosfat (PO4- $\left.{ }^{-}\right)$di Perairan Sungai Citarum dan Anak Sungainya dengan Metode Asam Askorbat. Teknisi Litkayasa Balai Penelitian Pemulihan dan Konservasi Sumber Daya Ikan.

Legowo, Anang, M. dan Nurwantoro. 2004, Analisis Pangan,. Program Studi Teknologi Hasil Ternak Fakultas Peternakan Universitas Diponegoro, Semarang

Prihandana, R. 2007. Bioetanol ubi kayu bahan bakar masa depan. Agromedia Pustaka. Jakarta.

Peraturan Menteri Lingkungan Hidup Republik Indonesia Nomor 5 Tahun 2014. Baku Mutu Air Limbah. Republik Indonesia.

Prayitno, H.T. 2008. Pemisahan Padatan Tersuspensi Limbah Cair Tapioka dengan Teknologi Membran Sebagai Upaya Pemanfaatan dan Pengendalian Pencemaran Lingkungan. Program Magister Ilmu Lingkungan. Program Pascasarjana. Universitas Diponegoro. Semarang.

Rahmatul, R.H., Avief, N., Nonot, S., Siti, N. 2013. Produksi biogas dari limbah cair industri tepung tapioka dengan reaktor anaerobik 3.000 liter berdistributor. Jurnal Teknik Pomits. 2(1): 2337-3539.

Suprapti, L. 2005. Pembuatan Tahu. Kanisius. Yogyakarta.

Sudjadi dan Rohman, A., 2004, Analisis Obat dan Makanan, Pustaka Pelajar, Yogyakarta

Yang, C., Zhong, Y., Ding, K., Zhang. 2008. Growth of Chlorella pyrenoidosa in wastewater from cassava ethanol fermentation. World J Microbiol Biotechnol. 24: 2919-2925. 